\title{
Ovariectomy Decreases Osteogenetic Activity in Rat Bone
}

\author{
Masae S. Goseki, Naomi Omi, ${ }^{1}$ Asako Yамамото, ${ }^{1}$ Shinichiro Oida, \\ Ikuko Ezawa, ${ }^{1}$ and Satoshi SASAKI \\ Department of Biochemistry, Faculty of Dentistry, Tokyo Medical and \\ Dental University, Bunkyo-ku, Tokyo 113, Japan \\ ${ }^{1}$ Department of Food and Nutrition, Japan Women's University, \\ Bunkyo-ku, Tokyo 112, Japan
}

(Received September 29, 1995)

\begin{abstract}
Summary The purpose of this study was to investigate the effect of ovariectomy on osteoinductive activity in the bone in rat. Homograft implantation of decalcified humeral diaphysis from ovariectomized or sham-operated rats was performed and harvested after several time periods. A significant decrease in bone induction was found in terms of soft $\mathrm{X}$-ray photography, alkaline phosphatase activity, mineral content and expression of osteocalcin (BGP; bone gla-protein) in the implants from the ovariectomized group in comparison to those from the sham-operated animals. This result suggested that the level of osteoinductive activity, probably due to bone morphogenetic protein, decreased in ovariectomized animals.
\end{abstract}

Key Words alkaline phosphatase (ALP), ovariectomy (OVX), osteocalcin (BGP), bone morphogenetic protein (BMP), osteoinduction

The increased incidence of fractures accompanying osteoporosis is a serious problem in the aged population. The common type of osteoporosis is the postmenopausal bone loss associated with ovarian hormone deficiency. The balance between bone formation and resorption is regulated by the actions of various hormones and growth factors on bone cells. Estrogen is recognized as one of the most important factors critical to the maintenance of bone mass and its administration has been shown to decrease the rate of bone loss and fracture occurrence in post-menopausal osteoporotic women (1-3). Several investigations on the effect of estrogen on bone metabolism indicated that this hormone inhibits bone loss by stimulating osteoblast function or by attenuating osteoclast activity, or both (4-6). Takano-Yamamoto and Rodan (6) reported a beneficial effect of estradiol on the trabecular bone maintenance in ovariectomized (OVX) rats. According to Jilka et al. (7), OVX resulted in an interleukin-6-mediated stimulation of osteoclastogenesis. However, the exact mechanism of estrogen on skeleton homeostasis remains unclear. It is well established that decalcified bone matrix, when implanted into 
extraskeletal sites in a host animal, induces differentiation of cartilage and bone $(8$, 9). Several species of bone morphogenetic protein (BMP) responsible for bone induction have been identified (10-13). BMP was also found to stimulate alkaline phosphatase (ALP) activity in osteoblastic MC3T3-E1 cells in vitro (14). A decrease in osteoinduction by decalcified bone matrix in vitamin D-deficient rats was reported by Turner et al. (15). Hashimoto et al. (16) reported that administration of exogenous estradiol mainly enhanced bone formation and partly suppressed bone resorption in male mice into which pellets containing osteosarcomaderived BMP had been implanted. Recently, we revealed that voluntary running exercise increased osteoinductive activity in rat bone (17).

This study was undertaken to investigate the effect of OVX on osteoinductive activity in the bone in an experimental animal model. The BMP activity in the bone from the OVX or control sham-operated groups was determined by implanting decalcified bone matrix into host animals. A significant decrease in bone formation was observed in terms of mineral content, expression of osteocalcin (BGP) and radiophotography of the implanted bone matrix from the OVX group compared to the control animals. We also examined ALP (ortho-phosphoric monoester phosphohydrolase, alkaline optimum, EC 3.1.3.1) activity in bone and serum as a maker of bone formation.

\section{MATERIALS AND METHODS}

Animals. A total of 40 Sprague-Dawley strain female rats (6 weeks old) were divided into two groups. Rats in one group $(n=20)$ were bilaterally ovariectomized under ether anesthesia. The other group animals $(n=20)$ were given a sham-operation. In order to induce osteoporosis, all rats were fed on a low-calcium diet which consisted of $0.01 \% \mathrm{Ca}$ and $0.3 \%$ phosphorus for the first 28 days and then switched to a diet of $0.3 \% \mathrm{Ca}$ and $0.3 \% \mathrm{P}$ for 28 days $(18,19)$. The details of the diet composition is shown in Table 1 . The diet and purified water by ion-exchange were given ad libitum to animals which were weighed periodically. All animals were fasted overnight before sacrifice.

Serum and bone sampling. Blood was collected from the abdominal aorta under ether anesthesia and serum was obtained by centrifugation. Both humeri were dissected out and the diaphyses cleaned of soft tissue and bone marrow were rinsed with $0.9 \% \mathrm{NaCl}$. One humeral diaphysis was mechanically crushed and homogenized with a Polytron homogenizer (Kinematica, Switzerland) in $10 \mathrm{~mm}$ Tris- $\mathrm{HCl}$ buffered saline containing $1 \%$ Triton $\mathrm{X}-100$ (pH 7.7). After centrifugation at $10,000 \times g$ for $10 \mathrm{~min}$, the supernatant of bone homogenate was collected and used for the protein determination and ALP assay. The other humerus was decalcified and the bone induction activity of the matrix was assayed by the implantation experiment.

Preparation of bone matrix and implantation. The humeral diaphysis was decalcified with $0.6 \mathrm{~N} \mathrm{HCl}$ for $48 \mathrm{~h}$ at $4{ }^{\circ} \mathrm{C}$ and excess acid was washed out 
Table 1. Composition of the experimental diets (\%).

\begin{tabular}{lcc}
\hline \multicolumn{1}{c}{ Constituents } & $\begin{array}{c}\text { Low } \mathrm{Ca} \text { diet } \\
0.01 \% \mathrm{Ca} \\
0.3 \% \mathrm{P}\end{array}$ & $\begin{array}{c}0.3 \% \mathrm{Ca} \\
0.3 \% \mathbf{P}\end{array}$ \\
\hline Glucose monohydrate & 65.1 & 64.7 \\
Casein (vitamin-free) & 18.0 & 18.0 \\
Cottonseed oil & 10.0 & 10.0 \\
Roughage & 3.0 & 3.0 \\
Ca- and P-free salt mixture (a) & 2.0 & 2.0 \\
Equimolar mixture of $\mathrm{KH}_{2} \mathrm{PO}_{4}$ and $\mathrm{K}_{2} \mathrm{HPO}_{4}$ & 1.39 & 1.03 \\
CaCO & 0.005 & 0.74 \\
Cystine & 0.2 & 0.2 \\
Water-soluble vitamin mixture (b) & 0.1 & 0.1 \\
Fat-soluble vitamin mixture & $(\mathrm{c})$ & (c) \\
Choline chloride & 0.2 & 0.2 \\
\hline
\end{tabular}

(a) $\mathrm{Ca}$ - and P-free salt mixture (in \%). $\mathrm{KCl}: 57.7, \mathrm{NaCl}: 20.9, \mathrm{MgSO}_{4}: 17.9$, $\mathrm{FeSO}_{4} \cdot 7 \mathrm{H}_{2}: 3.22, \mathrm{CuSO}_{4} \cdot 5 \mathrm{H}_{2} \mathrm{O}: 0.078, \mathrm{NaCl}: 20.9, \mathrm{CoCl}_{2} \cdot 6 \mathrm{H}_{2} \mathrm{O}: 0.004, \mathrm{KI}: 0.01$, $\mathrm{MnSO}_{4} \cdot 5 \mathrm{H}_{2} \mathrm{O}: 0.06, \mathrm{ZnSO}_{4} \cdot 7 \mathrm{H}_{2} \mathrm{O}: 0.44$, and $\left(\mathrm{NH}_{4}\right)_{6} \mathrm{Mo}_{7} \mathrm{O}_{24} \cdot 4 \mathrm{H}_{2} \mathrm{O}: 0.005$. (b) The water-soluble vitamin mixture (in \%). Thiamine: 0.5 , riboflavin: 0.5 , pyridoxine: 0.5 , calcium pantothenate: 2.8 , nicotinamide: 2.0 , inositol: 20.0 , folic acid: 0.02 , vitamin $\mathrm{B}_{12}$ : 0.5, biotin 0.01 and glucose monohydrate: 73.7. (c) The rats received a supplement of the following fat-soluble vitamins in cottonseed oil three times a week. $\beta$-carotene: $70 \mu \mathrm{g}, 2$-methyl-1,4-naphthoquinone: $105 \mu \mathrm{g}$, tocopherol: $875 \mu \mathrm{g}$ and vitamin $\mathrm{D}_{3}: 525 \mathrm{IU}$.

exhaustively with distilled water at $4{ }^{\circ} \mathrm{C}$ until $\mathrm{pH}$ 7.0. The matrix of diaphysis was lyophilized and weighed and implanted intraperitoneally into a host rat (SpragueDawley strain male, 7 weeks old, 225-250 g). After 1 week $(n=4), 3$ weeks $(n=$ $6), 5$ weeks $(n=6)$ and 7 weeks $(n=4)$, the implants were extirpated and the bone formation was determined.

Examination of the implant. The implant was dissected out and soft tissue was carefully removed. Radiophotography of the implant was taken with a soft $\mathrm{X}$-ray apparatus (M-40, Sofron Corp.) for $12 \mathrm{~min}$ at $38 \mathrm{kV}$ and $45 \mathrm{~mA}$ on a Konica CS $100 \mathrm{E}$ film. The density of the soft X-ray photograph in an area of $1 \mathrm{~mm}$ (width) $\times 15 \mathrm{~mm}$ (length) was determined with a densitometer (TIF-64, Immunomedica Co.) and calculated using a reference of aluminum steps. After measurement of the fresh weight, each implant was cut into two parts and one part was homogenized in Tris- $\mathrm{HCl}$ buffer containing $1 \%$ Triton $\mathrm{X}-100(\mathrm{pH} 7.7)$ and centrifuged at $10,000 \times g$ for $15 \mathrm{~min}$. ALP activity and protein content in the supernatant were determined as described below. The other part was ashed at 550$600^{\circ} \mathrm{C}$ for $24 \mathrm{~h}$ and dissolved in $1 \mathrm{~N}$ nitric acid. Ca and $\mathrm{P}$ contents were determined by the methods described below.

Measurement of bone mineral density. The lumbar spine of experimental and control animals was also isolated and cleaned. The bone mineral density (BMD) of 
the fourth and fifth lumbar vertebrae was measured by dual-energy X-ray absorptiometry (DXA; Hologic QDR-1000 X-ray bone densitometer) as reported previously (18). A detector collimator with a single slit was applied on the X-ray generator and the scan was performed with an ultra-high resolution mode (rat mode, version 2.0 software).

Enzyme assay. ALP activity was measured with $10 \mathrm{~mm}$-nitrophenylphosphate as a substrate in $100 \mathrm{~mm}$ 2-amino-2-methyl-1,3-propanediol- $\mathrm{HCl}$ buffer, containing $5 \mathrm{mM} \mathrm{MgCl}_{2}, \mathrm{pH} 10.0$ at $37^{\circ} \mathrm{C}(20)$. The hydrolysis rate of $p$-nitrophenylphosphate was determined and expressed in units $(\mathrm{U}=\mu \mathrm{mol} p$-nitrophenol formed $/$ $\min )$.

Biochemical determinations. The protein concentration in the bone homogenate was determined by the method of Lowry et al. (21). Serum calcium was measured by atomic absorption spectrophotometry (AA-640-12 atomic absorption spectrophotometer, Shimadzu). Phosphorus was determined by the FiskeSubbarow method (22). Total protein in serum was measured by the biuret method (23).

Statistical methods. Student's $t$-test was used to analyze the differences between the OVX and sham-operated groups. A $p$ value less than 0.05 was estimated to be statistically significant.

Northern blot analysis. Five weeks after implantation, total RNAs were extracted from the decalcified humeral diaphyses of the OVX and sham-operated groups by the acid guanidinium thiocyanate-phenol chloroform method (24). Each RNA sample $(20 \mu \mathrm{g})$ was denatured at $65^{\circ} \mathrm{C}$ for $5 \mathrm{~min}$ with formaldehyde and formamide, electrophoresed on a $1.2 \%$ agarose gel with $2.2 \mathrm{M}$ formaldehyde, transferred to a nylon membrane (Zeta-Probe, Bio-Rad, Richmond, CA) and hybridized with ${ }^{32} \mathrm{P}$-labeled rat BGP cDNA of $0.6 \mathrm{~kb}(25)$ and rat glyceraldehydephosphate dehydrogenase (GAPDH) $\mathrm{cDNA}$ of $1.4 \mathrm{~kb}$ as a reference probe. Autoradiography was performed using a Kodak XRP-5 film (Kodak, Rochester, NY) with an intensifying screen at $-80^{\circ} \mathrm{C}$.

\section{RESULTS}

As shown in Table 2, food intake and body weight gain of OVX rats were significantly larger $(p<0.01)$ than those of sham-operated animals.

The effect of OVX on serum biochemical values is shown in Table 3. Levels of total protein, $\mathrm{Ca}$ and $\mathrm{P}$ of both groups were within normal range. No significant differences in serum calcium and phosphorus contents were found between the OVX and control groups. However, serum ALP activity in the OVX group was higher than that in the sham-operated group $(p<0.01)$. As shown in the upper part of the bar in Fig. 1, heat-labile ALP activity in serum, which was suggested to be the bone type ALP (17), was found to be higher in the OVX group than in the control group $(p<0.05)$. Heat-stable type ALP shown in the lower part of the bar was not affected by OVX. 
Table 2. Body weight gain, food intake and food efficiency during the experimental period.

\begin{tabular}{cccc}
\hline & $\begin{array}{c}\text { Body weight gain } \\
(\mathrm{g} / \text { day) }\end{array}$ & $\begin{array}{c}\text { Food intake } \\
(\mathrm{g} / \text { day })\end{array}$ & Food efficiency $^{\mathrm{a}}$ \\
\hline Sham & $1.38 \pm 0.15$ & $12.7 \pm 0.56$ & $0.11 \pm 0.01$ \\
OVX & $2.27 \pm 0.24^{* *}$ & $15.3 \pm 0.44^{* *}$ & $0.15 \pm 0.01^{*}$ \\
\hline
\end{tabular}

${ }^{\text {a }}$ Food efficiency: Body weight gain/Food intake.

Results are the $\mathbf{M} \pm \mathbf{S E}$ of 20 separate determinations.

* Significant difference $(p<0.05)$ between the Sham and OVX groups. ** Significant difference $(p<0.01)$ between the Sham and OVX groups.

Table 3. Effect of ovariectomy on serum alkaline phosphatase activity, total protein, calcium and phophorus contents.

\begin{tabular}{lcc}
\hline & Sham & OVX \\
\hline Serum & & \\
ALP $(\mathrm{U} / \mathrm{ml})$ & $54.91 \pm 2.80$ & $72.92 \pm 6.37^{* *}$ \\
Protein $(\mathrm{g} / \mathrm{dl})$ & $6.95 \pm 0.09$ & $6.11 \pm 0.34^{*}$ \\
Calcium $(\mathrm{mg} / \mathrm{dl})$ & $9.61 \pm 0.18$ & $9.23 \pm 0.26$ \\
Phosphorus (mg/dl) & $4.90 \pm 0.19$ & $4.71 \pm 0.19$ \\
\hline
\end{tabular}

$\mathrm{U}=\mu \mathrm{mol} p$-nitrophenol formed/min under the conditions described in "Materials and Methods."

Results are the $\mathbf{M} \pm \mathbf{S E}$ of 20 separate determinations.

* Significant difference $(p<0.05)$ between the Sham and OVX groups. ${ }^{* *}$ Significant difference $(p<0.01)$ between the Sham and OVX groups.

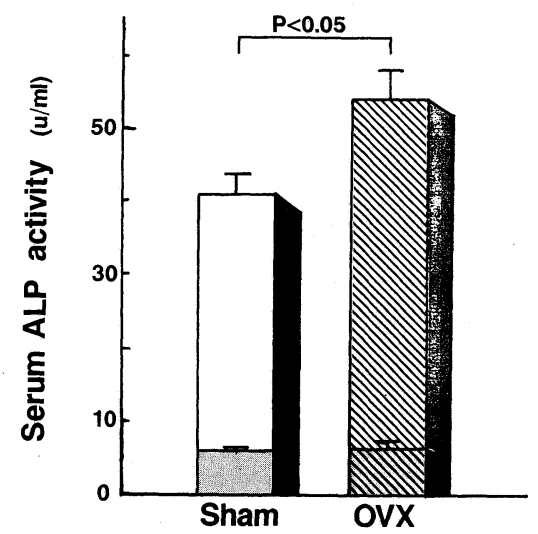

Fig. 1. Effect of ovariectomy on rat serum ALP at 8 weeks after OVX. The total ALP activity and the heat-labile ALP activity measured after the treatment at $56^{\circ} \mathrm{C}$ for $10 \mathrm{~min}$ (upper part of the bar) are shown. OVX, ovariectomized group; Sham, sham-operated group. 
The result of BMD of the lumbar spine is summarized in Fig. 2. The BMD value in the OVX group was significantly lower than that in the control group. Also, total or specific activity of ALP in the humeral bone from the OVX group was

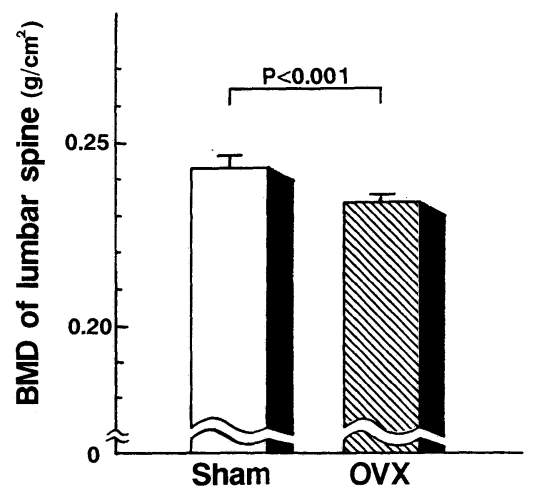

Fig. 2. Effect of ovariectomy on bone mineral density of the lumbar spine. Results are the $\mathrm{M} \pm \mathrm{SE}$ of 20 separate determinations.

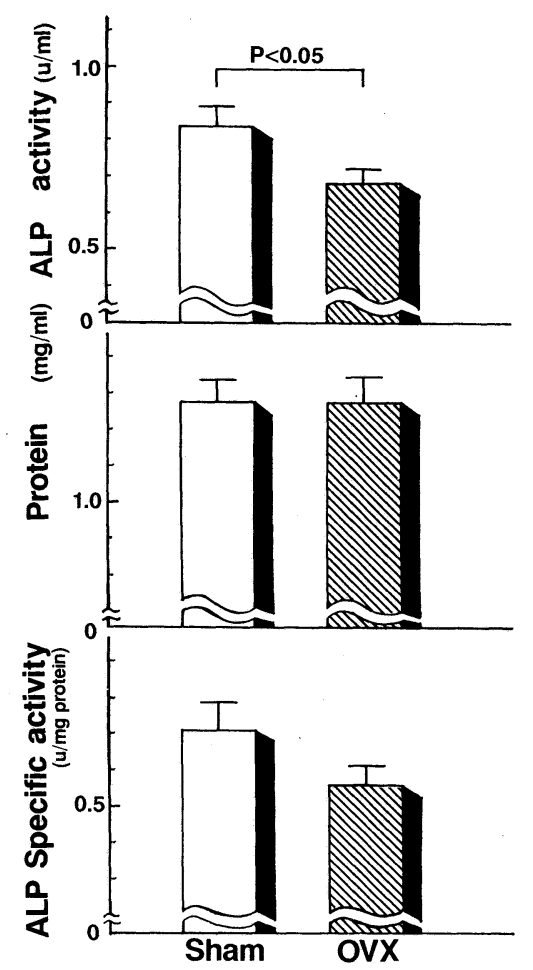

Fig. 3. ALP activity and total protein in the humerus. Specific ALP activity was calculated as the ALP activity per total protein. Results are the M \pm SE of 20 separate determinations. 
lower than that in the sham-operated group ( $p<0.05$, Fig. 3).

The decalcified humeral diaphyses from the OVX and control animals were implanted into host rats. After respective time periods, the implants were ex-

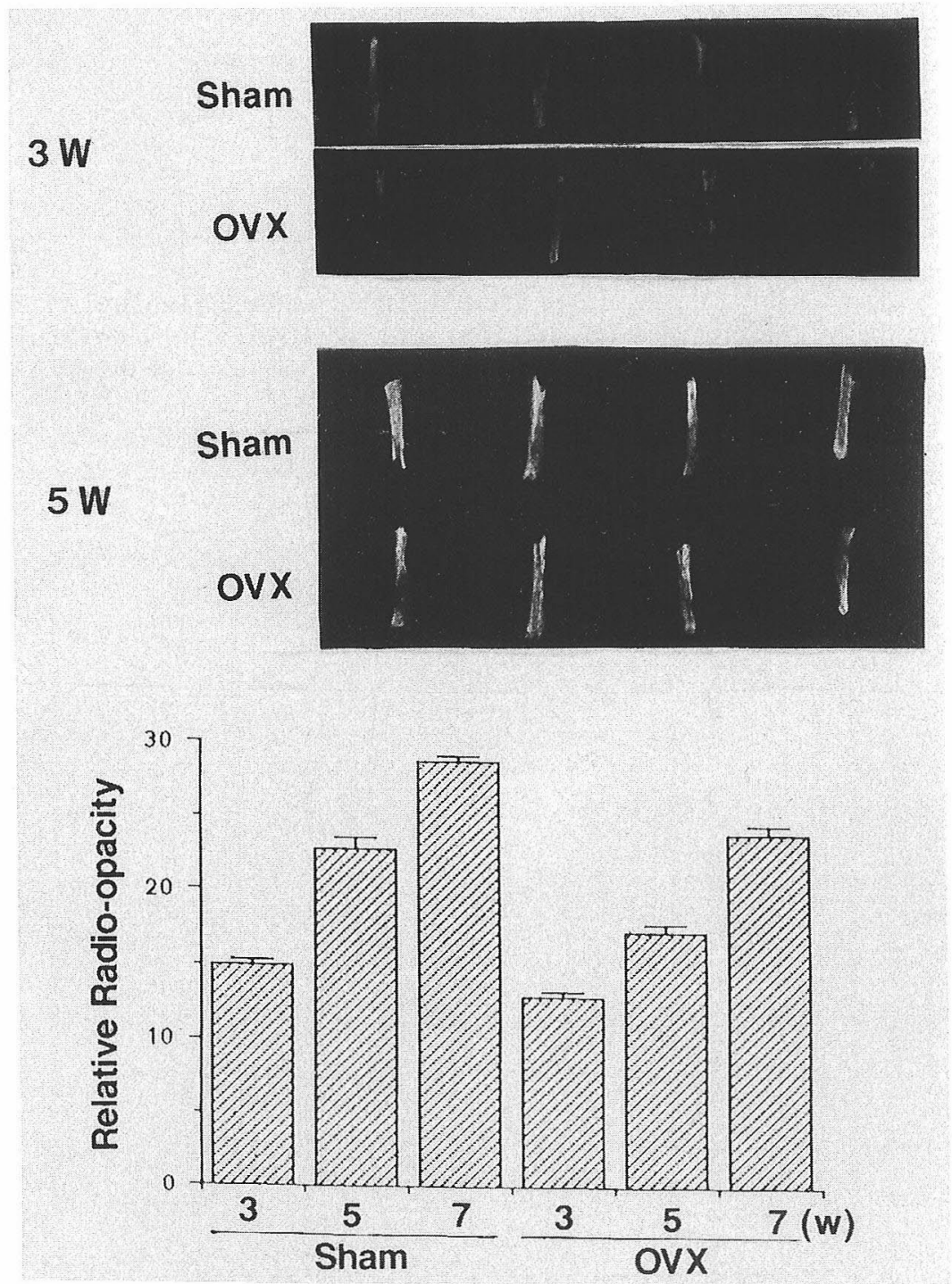

Fig. 4. The soft X-ray radiography of the implants of decalcified humeral diaphyses. Upper photographs show the decalcified humeral diaphyses 3 and 5 weeks after implantation into the host animals. The lower diagram shows the relative radio-opacity of the decalcified humeral diaphyses 3 weeks $(n=6), 5$ weeks $(n=$ $6)$ and 7 weeks $(n=4)$ after implantation. Results are the M \pm SE of 4 or 6 separate determinations. 


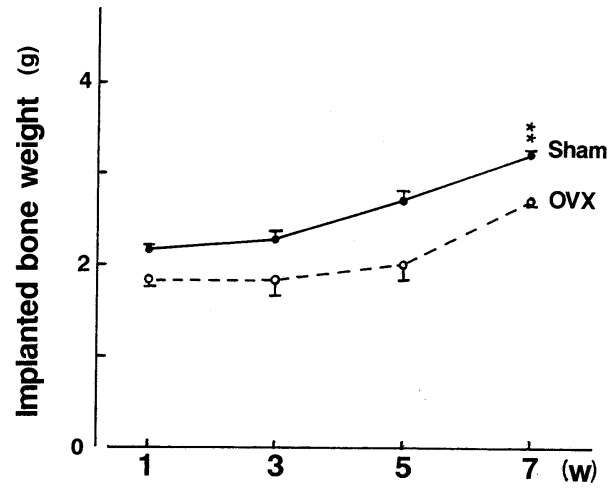

Fig. 5. Dry weight of the decalcified humeral diaphyses after implantation. Results are the $\mathrm{M} \pm \mathrm{SE}$ of 4 ( 1 and 7 weeks) or 6 ( 3 and 5 weeks) separate determinations. ** Significant difference $(p<0.01)$ between the values of the OVX and sham-operated groups.

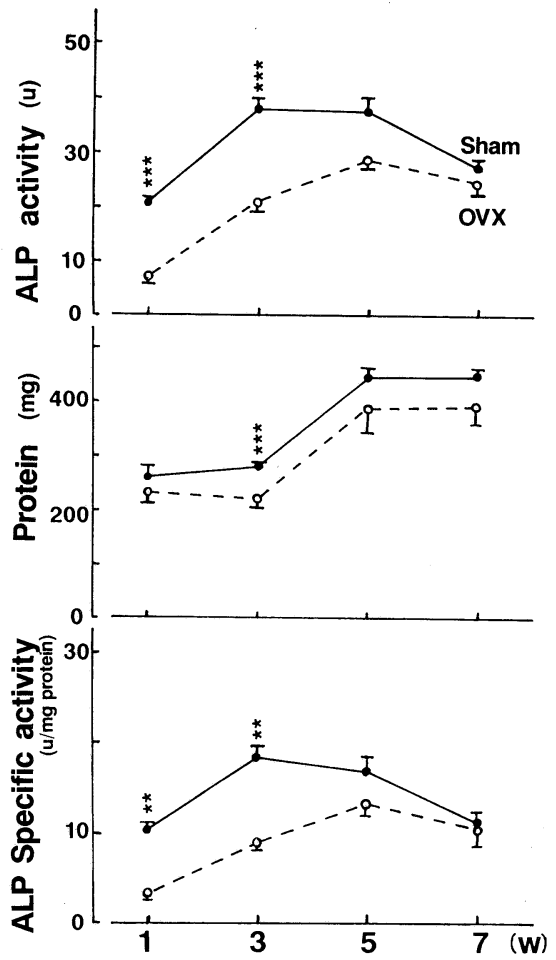

Fig. 6. Time course of ALP activity in units and in specific activity and total protein content in the implants of decalcified humeral diaphyses. Results are the $\mathrm{M} \pm \mathrm{SE}$ of 4 ( 1 and 7 weeks) or 6 ( 3 and 5 weeks) separate determinations. ** Significant difference $(p<0.01)$ between the values of the OVX and shamoperated groups. $* * *$ Significant difference $(p<0.001)$ between the values of two groups. 
tirpated and used for X-ray radiography and determination of ALP activity, protein, calcium and phosphorus contents. The results of the implant specimens in bone induction experiments are presented in Figs. 4-7.

The upper photographs in Fig. 4 show the soft X-ray appearances of the implants of the decalcified humeral matrix from the OVX and sham-operated groups, harvested 3 and 5 weeks after implantation. The lower diagram demonstrates photographic densities of the soft X-ray radiographs of the samples harvested after implantation. All the specimens from the OVX animals were significantly less radio-opaque when compared to the respective ones of the control group.

The dry weights of the implanted samples of both groups increased gradually (Fig. 5). However, that of the OVX group was always smaller than the shamoperated group (at 7 weeks; $p<0.01$ ). The time courses in the changes of ALP in total and specific activity and protein content in the decalcified matrix implants are shown in Fig. 6. The values of the implants from the OVX group were again lower than those from the sham-operated group at any time period.

Analyses of mineral content in the implant are shown in Fig. 7. Both calcium and phosphate contents in the humeral matrix implant increased almost linearly in the host and there were also significant differences between the OVX and control groups (at 5 weeks, $p<0.001$ ). As shown in Fig. 8, the expression of osteocalcin mRNA in the implants from the OVX group was lower than that from the sham-operated group at 5 weeks.

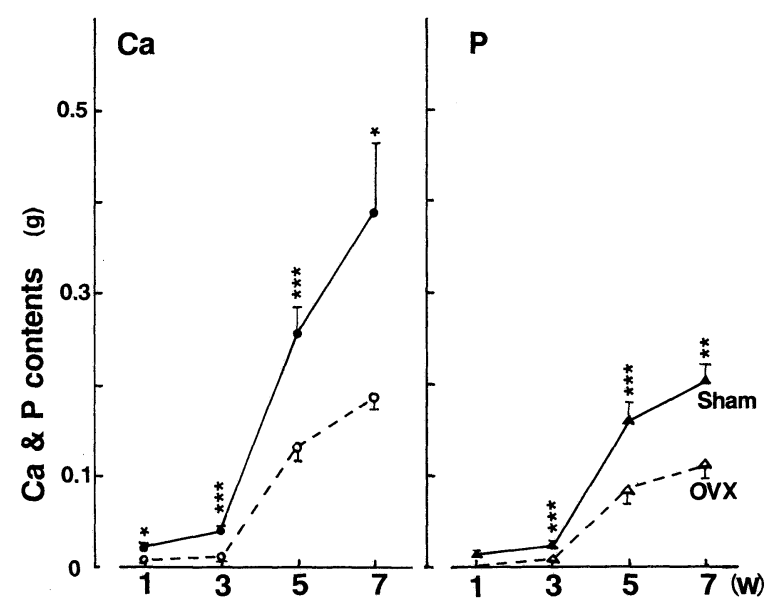

Fig. 7. Time course of mineral content in the implant of decalcified humeral diaphyses. Results are the $\mathrm{M} \pm \mathrm{SE}$ of 4 ( 1 and 7 weeks) or 6 ( 3 and 5 weeks) separate determinations. Data of calcium and phosphorus are expressed per $1 \mathrm{~g}$ of each implant. * Significant difference $(p<0.05)$ between the values of the OVX and sham-operated groups. ** Significant difference $(p<0.01)$ between the values of the two groups. *** Significant difference $(p<0.001)$ between the values of the two groups. 


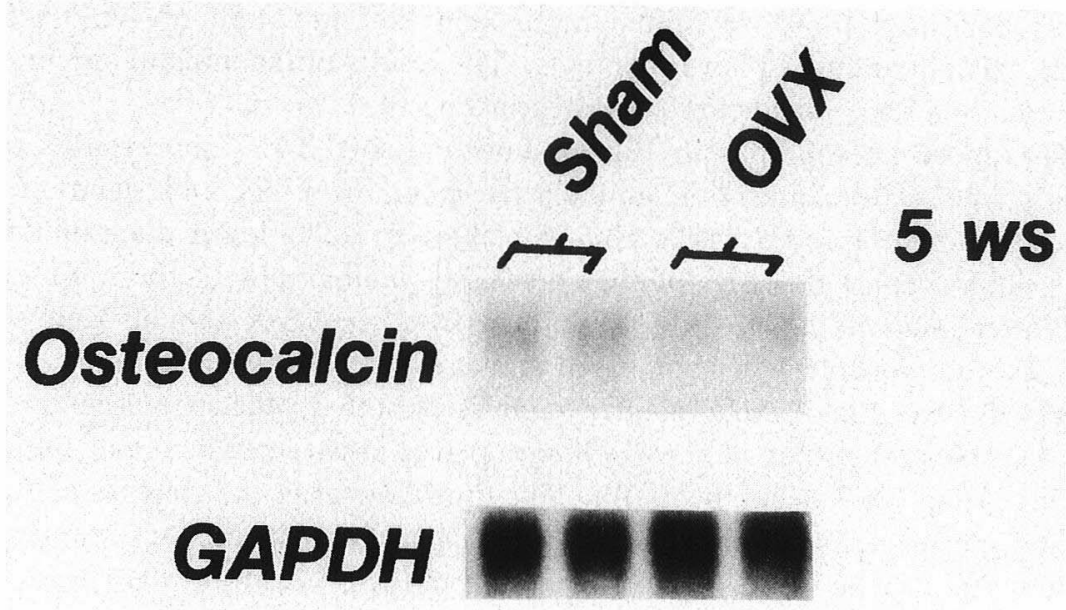

Fig. 8. Northern blot analysis of RNAs from the decalcified humeral diaphyses 5 weeks after implantation into the host animals were hybridized with a probe of rat osteocalcin cDNA or rat glyceraldehyde-phosphate dehydrogenase (GAPDH) cDNA.

Summarizing the results shown in Figs. 4-8, it was suggested that the bone formation activity, probably due to $\mathrm{BMP}$, in the bone was attenuated by ovariectomy.

\section{DISCUSSION}

In this experiment, the food intake and the body weight gain of the OVX rats were larger than those of the control animals (Table 2); nevertheless, BMD in the OVX group was significantly lower than that in the sham-operated group (Fig. 2). Moreover, ALP activity in the humeral bone of the OVX group decreased when compared to the value of the control group (Fig. 3). These data suggested there was bone loss due to ovarian hormone depletion in the OVX animals.

Biochemical parameters in serum may reflect the general conditions of the body and there were no significant differences in calcium or phosphorus content between the OVX and control animals (Table 3). Ca-regulating hormones might be functioning to maintain calcium and phosphorus at normal levels even in the absence of estrogen. In contrast, serum ALP activity increased by estrogen deficiency $(p<0.01$, Table 3$)$.

Previous studies suggested that rat serum ALP originated mainly from the intestine $(26,27)$. However, in the present study, the main fraction of ALP in rat serum was heat-labile bone-type isozyme (Fig. 1). By a 4-20\% gradient polyacrylamide gel electrophoresis, the major band with the same mobility as ALP in bone was found and this enzymic activity was lost by heat treatment. Therefore, 
intestinal type ALP was not dominant even under fasted conditions (17). The bone type ALP is thought to play a role in physiological skeletal mineralization. Serum bone type ALP activity in the OVX group was increased (Fig. 1), nevertheless ALP activity in the humeral bone of the OVX group decreased (Fig. 3). This enzyme may be partially degraded and released in a large quantity from the osteoblast cell membrane into serum under disadvantageous circumstances in the OVX animals similar to those in rickets or osteomalacia.

Radio-opacity and biochemical parameters, such as ALP activity, protein, calcium and phosphorus contents and the expression of osteocalcin mRNA, in the implanted bone matrix from the OVX animals were significantly lower or decreased (Figs. 4, 6-8). These results indicated that bone-forming factors in the bone of the OVX group were depleted. Several factors besides BMPs are known to stimulate osteogenesis and chondrogenesis. It has been suggested that transforming growth factor- $\beta$ s (TGF- $\beta$ s) stimulate bone formation in embryonic development and early fracture healing or ectopic bone formation induced by BMP $(28-30)$. However, TGF- $\beta$ itself could not induce ectopic bone formation in vivo.

Cesnjaj et al. (31) reported decreased osteoinductive potential of bone matrix from OVX rats by histological and analytical examinations at 3 weeks after implantation. They also studied the effect of the age of the host rats (6-27 weeks after OVX) and indicated that the amount of newly formed bone decreased with age 6 weeks after OVX. Their findings support our biochemical and mRNA expression findings. The present study clearly demonstrated that the boneinductive activity decreased in the OVX animals and it is suggested that reduction in the BMP activity may be one of the critical factors in the pathogenesis of post-menopausal osteoporosis.

\section{REFERENCES}

1) Lindsay, R., Hart, D. M., and Atken, J. M. (1976): Long-term prevention of postmenopausal osteoporosis by oestrogen. Lancet, 1, 1038-1040.

2) Christiansen, C., Christensen, M. S., and Transbol, I. (1981): Bone mass in postmenopausal women after withdrawal of oestrogen/gestagen replacement therapy. Lancet, 1, 459-461.

3) Ettinger, B., Genant, H. K., and Cann, C. E. (1985): Long-term estrogen replacement therapy prevents bone loss and fractures. Ann. Intern. Med., 102, 319-324.

4) Weisbrode, S. E., and Capen, C. C. (1877): The ultrastructural effect of estrogens on bone cells in thyroparathyroidectomized rats. Am. J. Pathol., 87, 311-322.

5) Wronski, T. J., Cintron, M., Doherty, A. L., and Dann, L. M. (1988): Estrogen treatment prevents osteopenia and depresseds bone turnover in ovariectomized rats. Endocrinology, 123, 681-686.

6) Takano-Yamamoto, T., and Rodan, G. A. (1990): Direct effects of 17 $\beta$-estradiol on trabecular bone in ovariectomized rats. Proc. Natl. Acad. Sci. U.S.A., 87, 2172-2176.

7) Jilka, R. L., Hangoc, G., Girasole, G., Wasseri, G., Williams, D. C., Abrams, J. S., Boyce, B., Broxmeyer, H., and Manolagas, S. C. (1992): Increased osteoclast 
development after estrogen loss: Mediation by interleukin-6. Science, 257, 88-91.

8) Urist, M. R. (1965): Bone: Formation by autoinduction. Science, 150, 893-899.

9) Urist, M. R., Hay, P. H., Dubuc, F., and Buring, K. (1969): Osteogenic competence. Clin. Orthop., 64, 194-220.

10) Urist, M. R., Huo, Y. K., Brownell, A. G., Hohl, W. M., Buyske, J., Lietze, A., Tempst, P., Hunkapiller, M., and DeLange, R. J. (1984): Purification of bone morphogenetic protein by hydroxy-apatite chromatography. Proc. Natl. Acad. Sci. U.S.A., 81, 371-375.

11) Wozney, J. M., Rosen, V., Celeste, A. J., Mitsock, L. M., Whitters, M. J., Kriz, R. W., Hewick, R. M., and Wang, E. A. (1988): Novel regulators of bone formation: Molecular clones and activities. Science, 242, 1528-1534.

12) Celeste, A. J., Innazzi, J. A., Taylor, R. C., Hewick, R. M., Rozen, V., Wang, F. A., and Wozney, J. M. (1990): Identification of transforming growth factor $\beta$ family members present in bone-inductive protein purified from bovine bone. Proc. Natl. Acad. Sci. U.S.A., 87, 9843-9847.

13) Sampath, T. K., Coughlin, J. E., Whetstone, R. M., Banach, D., Corbett, C., Ridge, R. J., Ozkaynak, E., Oppermann, H., and Rueger, D. C. (1990): Bovine osteogenic protein is composed of dimers of OP-1 and BMP-2A, two members of the transforming growth factor- $\beta$ superfamily. J. Biol. Chem., 265, 13198-13205.

14) Vukicevic, S., Luyten, F. P., and Reddi, A. H. (1990): Osteogenin inhibits proliferation and stimulates differentiation in mouse osteoblast-like cells (MC3T3-E1). Biochem. Biophys. Res. Commun., 166, 750-756.

15) Turner, T. R., Farley, J., Vandersteenhoven, J. J., and Epstein, S. (1988): Demonstration of reduced mitogenic and osteoinductive activities in demineralized allogeneic bone matrix from vitamin D-deficient rats. J. Clin. Invest., 82, 212-217.

16) Hashimoto, J., Takaoka, K., Yoshikawa, H., Miyamoto, S., Suzuki, S., and Ono, K. (1991): Preservation of ectopically induced bone in the mouse by estradiol. Bone, 12, 249-255.

17) Goseki (Sone), M., Omi, N., Oida, S., Ezawa, I., and Sasaki, S. (1995): Voluntary exercise increases osteogenetic activity in rat bones. Bull. Tokyo Med. Dent. Univ., 42, $1-8$.

18) Omi, N., Morikawa, K., Hoshiina, A., and Ezawa, I. (1992): Favorable effect of voluntary exercise on bone metabolism in a rat model of ovariectomized osteoporosis. J. Jpn. Soc. Nutr. Food Sci., 45, 271-276.

19) Omi, N., Goseki (Sone), M., Oida, S., Sasaki, S., and Ezawa, I. (1994): The nutritional evaluation of globin on maintenance of bone metabolism in ovariectomized osteoporotic rats. J. Nutr. Sci. Vitaminol., 40, 443-457.

20) Goseki (Sone), M., Oida, S., Nifuji, A., and Sasaki, S. (1990): Properties of alkaline phosphatase of the human dental pulp. J. Dent. Res., 69, 909-912.

21) Lowry, O. H., Rosebrough, N. J., Farr, A. L., and Randall, R. J. (1951): Protein measurement with the folin phenol reagent. J. Biol. Chem., 193, 265-275.

22) Fiske, C. H., and Subbarow, Y. (1925): The colorimetric determination of phosphorus. J. Biol. Chem., 66, 375-400.

23) Gornal, A. G., Bardawill, C. J., and David, M. M. (1949): Determination of serum proteins by means of the biuret reaction. J. Biol. Chem., 177, 751-766.

24) Chomczynski, P., and Sacchi, N. (1987): Single-step method of RNA isolation by acid 
guanidium thiocyanate-phenol-chloroform extraction. Anal. Biochem., 162, 156-159.

25) Celeste, A. J., Rosen, V., Buecker, J. L., Kriz, R., Wang, E. A., and Wozney, J. M. (1986): Isolation of the human gene for bone gla protein utilizing mouse and rat cDNA clones. EMBO J., 5, 1885-1890.

26) Madsen, M. B., and Tuba, J. (1952): On the source of the alkaline phosphatase in rat serum. J. Biol. Chem., 195, 741-750.

27) Saini, P. K., and Posen, S. (1968): The origin of serum alkaline phosphatase in the rat. Biochem. Biophys. Acta, 177, 42-49.

28) Joyce, M. E., Roberts, A. B., Sporn, M. B., and Bolander, M. E. (1990): Transforming growth factor- $\beta$ and the initiation of condrogenesis and osteogenesis in rat femur. J. Cell. Biol., 110, 2195-2207.

29) Bentz, H., Nathan, R. M., Rosen, D. M., Armstrong, R. M., Thompson, A. Y., Segarini, P. R., Mathews, M. C., Dasch, J. R., Piez, K. A., and Syedin, S. M. (1989): Purification and characterization of a unique osteoinductive factor from bovine bone. J. Biol. Chem., 264, 20805-20810.

30) Finkelman, R. D., Linkhart, T. A., Mohan, S., Lau, K.-H. W., Baylink, D. J., and Bell, N. H. (1991): Vitamin D deficiency causes a selective reduction in deposition of transforming growth factor $\beta$ in rat bone: possible mechanism for impaired osteoincuction. Proc. Natl. Acad. Sci. U.S.A., 88, 3657-3660.

31) Cesnjaj, M., Stavljenic, A., and Vukicevic, S. (1991): Decreased osteoinductive potential of bone matrix from ovariectomized rats. Acta. Orthop. Scand., 62, 471-475. 